\title{
Menggagas Pendidikan Berbasis Nilai-Nilai Civil Society di Madrasah
}

\author{
Baharuddin $^{1}$
}

\begin{abstract}
Abstrac
In an effort to realize the civil society (civil society) need for serious efforts to build and develop civic cultur (cultural refinement). Compressive point, the social aspect and the social networks that are considered a weak point for the creation of a strong horizontal social entities. With an emphasis on that aspect, is expected madrasa can lead to cooperation among citizens in resolving public issues around it. The existence of social change in valuesbased education civil society produces promising practices, but not a few social changes it gave birth to the contrary, become more childbirth social practices that "do not educate". Where the importance we look back at how the process of social change in education based on the values of civil society could bring about a change in the desired direction.
\end{abstract}

Keyword: Madrasah, Civil Society, learning Society

\section{A. Pendahuluan}

Di Indonesia, istilah civil society telah lama menjadi perbincangan di antara para ilmuan atau pun para pakar. Beragam istilah mereka gunakan dalam perbincangannya. Ada yang menggunakan istilah civil society, masyarakat sipil, ada pula yang memakai istilah masyarakat madani. Perbincangan istilah tesebut tidak lain mengarah pada bagaimana melakukan usaha-usaha penguatan masyarakat, "Masyarakat yang berkeadilan, yang menjunjung tinggi Hak Asasi Manusia (HAM), memahami nilai-nilai pluralisme, dan berkeadaban (civility)".

Madrasah sebagai lembaga pendidikan Islam di Indonesia dituntut pula mampu memainkan peran dalam membentuk tatanan civil society. Proses pengembangan kapasitas fungsional lembaga pendidikan seperti madrasah dalam ikut serta memberikan kontribusi dalam membentuk tatanan civil society dilakukan dengan cara (1)

1 Dosen Fakultas Ilmu Tarbiyah Dan Keguruan Universitas Islam Negeri Maulana Malik Ibrahim Malang Jl. Gajayana No. 50 Malang 65144. 
kegiatan pembelajaran diintegrasikan dengan nilai-nilai yang menjadi pilar pokok civil society, dan (2) proses pembelajaran didukung pula dengan kemampuan guru mengaitkan mata pelajaran dengan isu-isu civil society. Dalam konteks ini, pembelajaran civil society di madrasah menjadi suatu proses perencanaan dan penyusunan sistem pembelajaran civil society yang dapat menjadi bahan ajar dan acuan yang digunakan untuk memperkaya dan mmperkuat tujuan pendidikan nasional dalam aspek kemanusiaan (Suparlan, 2011: 79).

Perlunya pengarusutamaan wacana pemikiran civil society dalam dunia pendidikan Islam terutama madrasah dikarenakan isu seputar civil society, yang di Indonesia telah diterjemahkan menjadi "masyarakat sipil" atau "masyarakat madani", sebenarnya merupakan imbas dari perkembangan pemikiran yang terjadi di dunia Barat, khususnya di negara-negara industri maju, tepatnya Eropa Barat dan Amerika Serikat (Dawam, 1999:133).

civil society merupakan terjemahan dari bahasa latin, "civilis societas". Masyarakat Madani adalah masyarakat yang dapat mengaktualisasikan Islam dalam kebersamaan atau pewujudan tauhid sosial penuh keterbukaan, meminjam istilahnya Damardjati Supadjar (Widodo, dkk, 2000: 34). Kata "Madani" itu sendiri berasal dari bahasa Arab yang artinya civil atau civilized (beradab). Istilah Masyarakat Madani adalah terjemahan dari civil society (Qodri, 2004: 126).

Akan tetapi, walaupun di Indonesia istilah masyarakat madani telah memasyarakat, dan maknanya "sejalan" dengan semangat Al-Qur'an, sampai saat ini belum ada respon yang "positif" dari masyarakat itu sendiri. Oleh karena itu, pengelola madrasah perlu merespon keberadaan civil society dalam bentuk mengakomodasi nilai dan materi civil society dalam sistem pembelajaran yang dianut. Operasional pengintegrasian pembelajaran civil society di madrasah memang perlu dilakukan secara cermat. Paling tidak Hamalik sudah menegaskan tigal hal penting dalam mengembangkan kurikulum madrasah yang disisipi dengan nilai-nilai civil society, yakni:

a) Prinsip keseimbangan; keseimbangan secara proporsional dan fungsional, antara materi keislaman dan materi civil society, antara semua mata ajaran, dan antara aspek-aspek perilaku yang ingin dikembangkan. 
b) Prinsip keterpaduan; dengan melibatkan semua pihak, baik di tingkat sekolah maupun intersektoral dalam merumuskan kesepakatan tentang pengimplementasian nilai-nilai civil society di madrasah. Keterpaduan juga dalam proses pembelajaran civil society, baik dalam interaksi antara siswa dan guru maupun antara teori dan praktek.

c) Prinsip mutu; berorientasi pada pendidikan mutu dan mutu pendidikan. Pendidikan mutu berarti pelaksanaan pembelajaran yang bermutu, sedangkan mutu pendidikan berorientasi pada hasil pendidikan yang berkualitas.

Melalui penanaman nilai-nilai civil society diharapkan memunculkan kesadaran perlunya civil society di kalangan umat Islam. Hal ini penting dilakukan agar tidak terjadi stereotip tentang civil society sebagai produk impor dari luar negeri yang mengancam tatanan kebangsaan dan kemasyarakatan. Agar kesadaran masyarakat terus meningkatkan tentang penting nilai-nilai civil society maka perlu dilakukan langkah kongkret mengembangkan nilai-nilai civil society dalam dunia pendidikan Islam. Hal ini sebagaimana dikatakan Magnis Suseno (Widodo dkk, 2000:55) yang mengatakan keberadaan masyarakat madani sejatinya didekati secara faktual dan bukannya dengan pendekatan normatif. Langkah-langkah kongkrit tersebut dapat dilakukan dengan cara sebagai berikut: (1) pemilihan penyusunan tujuan pendidikan nilai-nilai civil society baik itu tujuan jangka panjang, jangka menengah maupun jangka pendek. (2) Pemilihan isi pendidikan nilai-nilai civil society yang harus sesuai dengan tujuan Islam serta mencakup ranah pengetahuan, sikap dan keterampilan. Setiap unit kurikulum nilai-nilai civil society harus disusun berdasarkan urutan yang logis dan sistimatis. (3) Pemilihan proses belajar mengajar nilai-nilai civil society dengan menggunakan metode yang sesuai. (4) Pemilihan dan penentuan media dan alat pengajaran nilai-nilai civil society diharuskan baik dan tepat, serta (5) Pemilihan kegiatan penilaian ataupun tes yang tepat sesuai dengan tujuan dan isi nilai-nilai civil society tersebut (Syaodih, 2002: 132-134).

Namun, yang terpenting adalah adanya wacana pembelajaran masyarakat madani di madrasah, melainkan bagaimana masyarakat memahami wacana masyarakat madani di Indonesia secara lebih komprehensif. Secara normatif dapat ditanyakan: bagaimana 
masyarakat madani dalam perspektif Islam dapat diperkuat apalagi diwujudkan? Kemana sebaiknya pendidikan nilai-nilai civil society dalam pandangan Islam diarahkan? Maka, "Masyarakat Madani" tentu bukan gagasan yang "diimpor" maupun gagasan yang "tidak diimpor", karena ia sama sekali bukan sebuah gagasan, melainkan sebuah kenyataan yang ada atau tidak ada, atau untuk sebagian ada tetapi tidak peduli apakah kita menggagasnya atau tidak.

\section{B. Kesadaran Nilai-Nilai Civil Society di Madrasah}

Pada hakekatnya masyarakat madani (mengikuti faham Hegel, 1770-1851 M) adalah kehidupan masyarakat di luar lingkungan keluarga, primordial atau lingkungan kenalan pribadi yang diminati secara pribadi, di satu pihak dan di lain pihak (barang kali diatur, tetapi) tidak ditentukan, diadakan oleh negara. Jadi, secara filosofis, masyarakat madani dikembangkan dalam madrasah karena dinamikanya sendiri, bukan karena dorongan, apalagi inisiatifinisiatif dari negara. Input-input dari negara (yang tentu terusmenerus ada) ditampung dengan respon yang mandiri (hubungan negara-masyarakat madani bukan generatif), melainkan menurut ideal type-nya dialogal dialegtis. Pernyataan ini senada dengan apa yang ditegaskan oleh Luqman Hakim dalam Widodo Usman dkk, (Ed) 2000:132, bahwa masyarakat sipil (civil society), bermula dari pergumulan masyarakat Barat untuk mengurangi peranan negara (state) terhadap kehidupan masyarakat.

Hikam (1996:3) menilai pemahaman yang akurat mengenai masyarakat Madani memiliki kepentingan agar masyarakat Indonesia memahami wilayah-wilayah kehidupan sosial yang terorganisasi dan bercirikan antara lain; kesukarelaan (voluntary), keswasembadaan (self-generation), dan keswadayaan (self-supporting), kemandirian tinggi berhadapan dengan negara, dan keterkaitan dengan normanorma atau nilai-nilai hukum yang diikuti oleh warganya. Dengan demikian, untuk menumbuhkan kesadaran tentang nilai-nilai civil society di madrasah tanpa ada kesalahpahaman, meminjam konsep Hamalik, dapat dilakukan dengan:

a) Merumuskan tujuan penanaman nilai-nilai civil society yang selaras dengan filsafat dan pendidikan nasional. Hal inilah yang menjadikan nilai-nilai civil society sebagai bahan dalam merumuskan tujuan institusional dan tujuan kurikulum pada 
madrasah.

b) Penyusunmateridannilai-nilaicivil society dilakukanataslandasan sosial budaya dan agama yang berlaku dalam masyarakat, lebih pada masyarakat dimana madrasah berada.

c) Penyusunan materi dan nilai-nilai civil society dilaksanakan dengan mempertimbangkan perkembangan peserta didik di madrasah, secara fisik dan psikologi

d) Penyusunan materi dan nilai-nilai civil society didasarkan atas keadaan lingkungan madrasah yang meliputi, lingkungan manusiawi, kebudayaan, ilmu pengetahuan dan teknologi, dan lingkungan hidup serta lingkungan alam.

e) Penyusunan materi dan nilai-nilai civil society bersumber kepada kebutuhan pembangunan, yang mencakup semua aspek pembangunan.

f) Penyusunan materi dan nilai-nilai civil society dikembangkan dari ilmu pengetahuan dan teknologi yang sesuai dengan sistim nilai dan kemanusiawian serta budaya bangsa. (Hamalik: 2009: 34).

Sebagai sebuah ruang politik dan kajian pendidikan di madrasah, civil society adalah suatu wilayah yang menjamin berlangsungnya perilaku, tindakan dan refleksi mandiri, dan tidak terkungkung oleh kondisi kehidupan material, serta terserap dalam jaringan-jaringan kelembagaan politik resmi. Oleh karena itu, pendidikan berbasis nilai-nilai civil society di madrasah, tersirat pentingnya pemahaman masyarakat madani. Hal itu berimbas kepada tumbuhnya kesadaran warga madrasah dalam memposisikan diri di ruang publik yang bebas, di mana tempat komunikasi bisa dilakukan oleh warga masyarakat, juga dipahami sebagai sesuatu bukan sebagai sesuatu yang jadi.

Keberadaan pembelajaran masyarakat madani di madrasah, tidak lain dimaksudkan untuk menjelaskan bahwa upaya merealisasikan atau mewujudkan wacana masyarakat madani harus dilakukan semenjak di bangku sekolah. Hal ini diperlukan prasyarat-prasyarat yang menjadi nilai universal dalam penegakan masyarakat madani khususnya di lingkungan masyarakat muslim. Prasyarat ini tidak dapat dipisahkan satu sama lain atau hanya mengambil salah satunya saja, melainkan merupakan satu kesatuan yang integral yang menjadi dasar dan nilai bagi eksistensi masyarakat madani di lingkungan 
masyarakat muslim. Karakteristik tersebut antara lain adalah adanya Free Public Sphere, demokrasi, toleransi, pluralisme, keadilan sosial (social justice) dan berkeadaban (Rozak, dkk. (Ed) 2003:247)

Upaya mewujudkan civil society dilingkungan madrasah, tentunya beragam cara dapat dilakukan. Di antaranya dengan mengagendakan politik dan ekonomi dalam format reformasi oleh Riswanda Imawan, keadilan dan kesetaraan gender oleh Mary Astuti, wudlu konseptual dan eksistensial oleh Darmadjati Supadjar (Widodo, dkk (Ed):34, 103, 219) dan lain sebagainya. Namun, dari sekian usaha dan upaya yang mencoba diterapkan pada hakekatnya tidak terlepas dari kondisi dan peran madrasah yang ada di Indonesia. Oleh karenanya penulis memandang konsep masyarakat belajar (learning society) cukup strategis dan berpeluang dalam upaya mewujudkan masyarakat madani (civil society) khususnya di lingkungan masyarakat muslim khususnya dengan mengoptimalkan peran madrasah sebagai ujung tombak pendidikan.

Pertanyaannya, kenapa harus masyarakat belajar (learning society)? Pendidikan berbasis nilai-nilai civil society di madrasah merupakan tonggak kehidupan manusia dalam mengamalkan nilainilai masyarakat madani dengan mudah dan benar. Pendidikan berbasis nilai-nilai civil society memiliki potensi kuat untuk mendorong timbulnya kesadaran memanusiakan manusia, sehingga mampu mengelola bumi beserta isinya (khalifah fi al-ardh). Serta dengan pendidikan berbasis nilai-nilai civil society-lah, bangsa ini bisa" "terjajah" oleh diskiriminasi, konflik, demoralisasi dan sebagainya. Sayangnya, pendidikan berbasis nilai-nilai civil society belum dianggap sebagai salah satu faktor pokok penyebab terpuruknya bangsa ini, walaupun hal ini termasuk keprihatinan bersama, meminjam istilah Indra Djati Sidi (2001:13). Tudingan-tudingan sebagian besar pengamat bahkan para politisi yang mengatakan bahwa ekonomi dan politiklah yang menentukan baik buruknya suatu bangsa, merupakan salah satu contohnya. Bangsa ini lupa, bahwa sesuatu harus dimulai dengan pendidikan berbasis nilai-nilai civil society yang baik. Pendidikan berbasis nilai-nilai civil society di negeri ini selalu dijadikan alat politik dan alat mencari popularitas (Djauzak Ahmad, Kompas, 17/01/2005). 
Faktanya, masalah pendidikan berbasis nilai-nilai civil society, kelihatannya tidak ada habis-habisnya menjadi wacana publik. Karena besaran masalah dan implikasinya terhadap kelangsungan eksistensi bangsa, pendidikan berbasis nilai-nilai civil society terlalu besar untuk diselesaikan oleh salah satu komponen sistem masyarakat kita, apakah itu pemerintah yang dalam hal ini "bertindak" sebagai pembuat kebijakan (public policy), lembaga pendidikan (sekolah), para pakar pendidikan, Lembaga Swadaya Masyarakat (LSM), atau komponen lainnya, semisal keluarga. (Syafnir, dkk. 2003:v). Bahkan, Syafnir Ronisef, (2003: viii), mengatakan bahwa pendidikan merupakan sarana strategis untuk meningkatkan kualitas bangsa. Oleh karenanya, kemajuan suatu bangsa dan kemajuan pendidikan adalah suatu determinasi; kebetulan, rangkaian yang terputuskan (Kamus Populer, 1994:106).

Meminjam konsep al-Ghazali, pendidikan berbasis nilai-nilai civil society dapat dijadikan sebagai proses memanusiakan manusia sejak masa kejadiannya sampai akhir hayatnya, melalui pelbagai ilmu pengetahuan, yang disampaikan dalam bentuk pengajaran secara bertahap, di mana proses pengajaran itu menjadi tanggung jawab orang tua (yang melahirkan dan yang mendidik, guru dan masyarakat) menuju pendekatan diri kepada Allah sehingga menjadi menusia yang sempurna (Ibnu Rusn, 1998:68). Pendapat Al-Ghazali di atas, secara konstektual semakna dengan apa yang ditegaskan oleh Indra Djati Sidi (2001:4) yang mengatakan bahwa persoalan pendidikan berbasis nilai-nilai civil society tidak hanya menjadi persolan "individu"-sekolah semata-, melainkan menjadi masalah masyarakat secara keseluruhan.

Pemahaman akan dunia pendidikan berbasis nilai-nilai civil society yang terfokus pada sistem pembelajaran madrasah pada aspek formal saja sejatinya tidaklah tepat. Konsep pendidikan (mendidik) yang ada seyogyanya diartikan secara luas. Hal ini dipahami untuk menyebut semua upaya guna mengembangkan tiga hal, yaitu: pandangan hidup, sikap hidup dan keterampilan hidup, dalam mengembangkan pendidikan berbasis nilai-nilai civil society. Sedangkan cara untuk mencapai ketiga-tiganya adalah ketika tiga jenis pendidikan dapat berjalan seperti yang diharapkan, pendidikan formal, informal, dan non formal. 
Noercholish Madjidmengatakan bahwa membincang pendidikan, tentu melibatkan banyak hal yang harus direnungkan. Oleh karena itu, pendidikanberbasisnilai-nilai civil societymeliputikeseluruhan tingkah laku manusia yang dilakukan demi memperoleh kesinambungan, pertahanan dan peningkatan hidup dalam mewujudkan nilai-nilai civil society di dalam masyarakat. Dengan proses tersebut, keseluruhan tingkah laku tersebut membentuk keutuhan manusia berbudi luhur (berakhlak karimah), atas dasar percaya atau iman kepada Allah dan bertanggung jawab pribadi di hari kemudian serta kesadaran untuk memahami nilai-nilai civil society sebagai sebuah kesalehan sosial (Indra, 2001:xi).

Pandangan Noercholish Madjid di atas, tampaknya sesuai dengan pemikiran Naquib Al-Attas dalam tulisannya tentang "Islamisasi Ilmu" (Pemikiran Islam Kontemporer, 2003:344) yang mengatakan bahwa pendidikan bertujuan untuk membentuk dan menghasilkan manusia yang "baik". Dengan kata lain, pendidikan berbasis nilainilai civil society adalah sesuatu yang secara bertahap ditanamkan ke dalam diri manusia dalam usaha membentuk tatanan kehidupan yang menghargai nilai-nilai perbedaan dan harmonisasi keragaman. Manusia adalah makhluk rasional, sehingga mereka mampu merumuskan makna-makna nilai-nilai civil society yang melibatkan penilaian, pembedaan, dan penjelasan.

Kehidupan manusia tidak dapat dikekang atau dibelenggu oleh manusia yang lainnya. Hal ini mengandung pengertian bahwa manusia bebas melakukan segala aktivitas yang dikehendakinya dengan tidak menghilangkan esensi serta nilai-nilai kemanusiaannya. Oleh karena itu, konsep berbasis nilai-nilai civil society seyogyanya dipahami oleh peserta didik di madrasah tidak hanya menjadi obyek, tapi juga menjadi subyek yang akan menciptakan suasana yang lebih kondusif dalam lingkungan pendidikan Islam dan dapat mencapai tujuan pendidikan berbasis nilai-nilai civil society secara komprehensif (Freire: 2001:60).

Dalam hal pendidikan berbasis nilai-nilai civil society, kita tidak mungkin hanya bertumpu pada madrasah atau yang lebih dikenal sebagai lembaga pendidikan formal, sekolah-dengan tetap 'berwajah' lama-, apalagi madrasah "diminta untuk bertanggung jawab atas tercipta dan lahirnya peserta didik yang dapat mengintegralkan tiga 
dimensi-kemampuan-, Intellectual Quotient (IQ), Emotional Quotient (EQ), dan Spiritual Quotient (SQ) berbasis nilai-nilai civil society. Oleh karena itu, masalah pendidikan berbasis nilai-nilai civil society tidak hanya menjadi masalah "individu" madrasah, melainkan menjadi masalah seluruh stakeholders pendidikan.

Madrasah memiliki posisi strategis dalam menginternalisasi nilainilai civil society di tengah masyarakat. Maka, sepatutnya, madrasah tidak hanya diartikan secara formal-institusional, melainkan ada di mana-mana, terutama dalam keluarga dan lingkungan masyarakat sekitar. Melalui proses tersebut, suasana pembelajaran berbasis nilainilai civil society yang diharapkan dapat melahirkan iklim kondusif bagi lahir dan berkembangnya, yang menurut Indra Djati Sidi, disebut "learning society" (masyarakat belajar).

Pembicaraan tentang konsep pendidikan berbasis nilai-nilai di madrasah bertujuan pada membentuk paradigma peserta didik yang sesuai dengan nilai-nilai kewajaran dan keadaban (civility). Semua umat muslim pasti mempunyai harapan dan cita-cita bagaimana sebuah kehidupan menuju kepada yang lebih baik. Karena itu, pendidikan berbasis nilai-nilai civil society pada gilirannya berperan mempersiapkan setiap peserta didik untuk selalu berprilaku penuh keadaban (civility). Keadaan inilah yang secara praktis sangat dibutuhkan dalam setiap gerak dan perilaku peserta didik dalam menghayati nilai-nilai civil society sebagai realitas sosial.

Pada sisi lain, kita sering menyaksikan adanya beberapa kasus yang berkorelasi dengan penindasan rakyat yang dilakukan oleh penguasa. Hal tersebut merupakan realitas yang sering dilihat, diamati dan didengar dalam setiap pemberitaan pers, baik media elektronika maupun media cetak. Misalnya, kasus penindasan yang terjadi di Indonesia, tatkala Orde Baru masih berkuasa, yakni penindasan terhadap keberadaan hak tanah rakyat yang diambil oleh penguasa dengan alasan pembangunan. Pengekangan dan pembungkaman pers dengan adanya pemberedelan beberapa media massa oleh penguasa, serta pembantaiaan para ulama (kyai) dengan dalil dukun santet sekitar tahun 1999 yang dilakukan oleh kelompok (oknum) yang tidak bertanggung jawab. Apabila ini yang sering terjadi, masihkah ada harapan terciptanya masyarakat madani di negeri ini?. 
Pertanyaan-pertanyaan tersebut pada akhirnya akan bermuara pada perlunya dikaji kembali kekuatan rakyat atau masyarakat (civil) dalam konteks "inteksirelationship", baik antara rakyat dengan negara, maupun antara rakyat dengan rakyat. Kedua pola hubungan interaktif tersebut akan memposisiskan rakyat sebagai bagian integral dalam komunitas negara yang memiliki kekuatan bargaining dan menjadi komunitas masyarakat sipil yang memiliki kecerdasan, analisa kritis yang tajam serta mampu berinteraksi di lingkungannya secara demokratis dan berkeadaban (Rosyada, dkk. 2003:237-238).

Pendidikan berbasis nilai-nilai civil society pada akhirnya akan berperan menciptakan masyarakat berkeadaban (civilize culture society), yaitu suatu masyarakat yang anggota-anggotanya mengetahui dan bisa terus menjalankan aturan dan mekanisme yang sudah dibuat dan disepakati bersama. Secara kontras-yang membedakannya dari kultur masyarakat primitif (primitif culture society)-budaya masyarakat berkeadaban cenderung memandang bahwa pemuasan kebutuhan dan hasrat (nafsu) itu tidak dianggap sebagai sesuatu yang penting untuk mempertahankan hidup. Budaya masyarakat berkeadaban dan mengorbankan kesenangan sementara demi meraih hidup kedepan yang lebih maju. Karena itu, kelompok masyarakat yang sudah "civilize" akan sangat menghormati aturan bersama yang sudah disepakati.

\section{Realitas Pendidikan Civil Society di Madrasah}

Selama ini, model pendidikan dan proses belajar di madrasah selalu berjalan tidak seimbang (not balance), antara kemauantujuan-pembuat kebijakan (public policy), pelaksana kebijakan, dan stakholders. Akibatnya, realitas pendidikan di madrasah dengan peserta didik "berjalan sendiri-sendiri". Kementerian Pendidikan dan Kebudayaan terkesan dengan rasa percaya diri yang cukup tinggi, melakukan "bongkar pasang" kebijakan (policy) 'hanya' demi menghindari anggapan "tambal sulam" kebijakan pendidikan, yang hal itu diasumsikan sebagai pikiran-pikiran "inovatif", pergantian kurikulum pendidikan misalnya-yang berdampak tidak "baik" dalam kacamata publik.

Pemerintah "tidak mau" melibatkan "publik terdidik" dalam membahas bagaimana sebaiknya sistem pendidikan itu dirancang dan diterpkan di negara ini. Bahkan mungkin, penyebab utama 
ketertinggalan kita dari negara lain dalam pelbagai kehidupan, entah ekonomi, hukum, pendidikan, dan lain-lain disebabkan oleh menkulturnya "sentralisasi" pengelolaan negara yang berlebihan (Kompas, 14/02/2005). Akhirnya, sampai saat ini kebijakan pendidikan (public policy), masih terkesan "demi menghabiskan proyek", bila sudah seperti ini, bagaimana nasib pendidikan kita ke depan? Tentunya, nasib pendidikan tidak hanya menjadi tanggung jawab pemerintah saja, melainkan menjadi tanggung jawab kita semua. Satu yang menjadi keniscayaan, masyarakat mesti selalu kritis melihat setiap kebijakan yang kerap kali tidak memihak terhadap masyarakat dan sering memihak pada "masyarakat elit kapitalis" di sana.

Dalam konteks pendidikan berbasis nilai-nilai civil society, pelaksana kebijakan termasuk para guru dituntut mampu mengembangkan materi pembelajaran yang memosisikan siswa sebagai subjek pembelajaran. Misalnya metode dan suasana pengajaran di madrasah, peserta didik dipersiapkan mau menerima seluruh informasi sekaligus untuk menelaah, mengkaji dan bahkan menghasilkan hasil belajar yang mampu melahirkan kreatifitas. Sayangnya, tatkala yang dipelajari di madrasah ternyata tidak integratif dengan kehidupan atau realitas sehari-hari, yang mereka saksikan bertolak belakang dengan pelajaran di madrasah.

Budaya dan mental semacam ini pada gilirannya membuat siswa tidak mampu mengaktifkan kemampuan otaknya dalam memahami berbasis nilai-nilai civil society. Akibatnya, mereka tidak memilki keberaniaan menyampaikan pendapat, lemah dalam penalaran dan lain sebagainya dalam mengupas problematika pendidikan berbasis nilai-nilai civil society. Demi membangun paradigma dan visi pendidikan berbasis nilai-nilai civil society yang mampu menjawab tantangan zaman, maka stakeholders madrasah harus menempuh dua gagasan, pertama: hendaknya mengubah paradigma teaching (mengajar) menjadi learning (belajar). Dengan perubahan ini, proses pendidikan berbasis nilai-nilai civil society menjadi "proses bagaimana belajar bersama antara guru dan anak didik" dalam memahami realitas sosial sebagai sebuah kekayaan harmoni.

Dalam konteks ini, guru juga termasuk dalam proses belajar berbasis nilai-nilai civil society, sehingga lingkungan madrasah menjadi learning society (masyarakat belajar). Hal ini sesuai dengan empat visi 
Baharuddin - Menggagas Pendidikan Berbasis Nilai-Nilai...

UNISCO (United Ntions Educational Scientif And Cultural Organization), sebagaimana dikutip Indra Djati Sidi dalam buku Menuju Masyarakat Belajar (2001: 25-26).

Keempat visi dimaksud adalah [1] Learning to think (belajar berpikir) yang berarti pendidikan berbasis nilai-nilai civil society berorientasi pada pengetahuan yang logis dan rasional, sehingga anak didik mampu bersikap kritis serta memiliki semangat (ghirah) yang tinggi, [2] Learning to do (belajar berbuat atau hidup) yang berarti bagaimana anak didik memiliki keterampilan menyelesaikan problem keseharian dalam konteks masyarakat madani, [3] Learning to life together (belajar hidup bersama) yang berarti bagaimana anak didik dapat memahami bahwa ia hidup di dunia ini tidak sendirian, termasuk makhluk sosial. Keempat visi tersebut pada akhirnya menjadi "Learning how to learn" ("belajar bagaimana belajar").

Alhasil, pendidikan berbasis nilai-nilai civil society di madrasah tidak hanya berorientasi pada nilai akademik yang bersifat pemenuhan aspek kognitif saja, melainkan juga berorientasi pada bagaimana "mencipta" anak didik yang bisa belajar dari lingkungan, dari pengalaman dan kehebatan orang lain, dari keaktifan dan luasnya hamparan alam-sehingga mereka mampu-untuk mengembangkan sikap-sikap kreatif dan daya berpikir imaginatif.

Kedua, gagasan dimaksud adalah berkaitan dengan metode pengajaran yang tidak lagi mementingkansubjeckmatter (pokokintinya) seperti yang tetuang dalam Garis-Garis Besar Progam Pelajaran [GBPP yang rigid] dari pada siswa itu sendiri. Sebab, pola seperti ini secara tidak langsung "memaksa" anak didik untuk menguasai pengetahuan dan melahap pelbagai informasi yang terkait dengan nilai-nilai civil society dari guru, tanpa memberi peluang pada anak didik untuk melakukan perenungan sescara kritis, guru memberi sesuai GBPP, anak didik menerima. Inilah sebenarnya yang biasa disebut dengan model "gaya bank" (banking system), meminjam istilah Paulo Freire. Teinspirasi dari Freire mengatakan bahwa pendidikan berbasis nilainilai civil society tidak hanya menekankan pada kesadaran kritis tapi juga kreatif, sanggup menciptakan terobosan penting dalam menjawab pelbagai persoalan masyarakat yang mengitarinya (Freire, 2004:10).

Pertanyaanya adalah apakah anak didik akan berstatus sebagai objek atau klien, dan ia berstatus sebagai subjek atau warga dalam 
pendidikan berbasis nilai-nilai civil society? (Zamrani, dalam Suyudi, 2005:279). Inilah sebenarnya yang harus ditelusuri sescara lebih mendalam. Selanjutnya, "status" inilah yang akan mengkonstruk anak didik menuju proses "menjadi", menjadi lebih baik atau sebaliknya!

Dengan demikian sebuah metode yang lebih cocok dan relevan bagi anak didik madrasah di masa sekarang dan akan datang, mutlak ditemukan untuk kemudian diterapkan. Apapun nama metode tersebut, bukan hal yang "penting", asalkan lebih menekankan peran aktif anak (peserta) didik. Guru tetap dianggap berpengalaman dan lebih banyak pengetahuannya, tapi ia bukan pemegang satu-satunya kebenaran, sebab kebenaran bisa jadi datang dari siswa. Jadi, metode tersebut bersifat dialogis menjadi suatu hal yang niscaya.

Negara berkembang seperti Indonesia, pengembangan pendidikan berbasis nilai-nilai civil society seyogyanya dilihat sebagai suatu proses kelangsungan peradaban bangsa. Oleh karena itu, faktor-faktor psiko budaya juga penting untuk diikutsertakan dalam merancang pendidikan, dan penting segera diciptakan karena situasi dan kodisi untuk kemudian keberhasilan suatu proses belajar akan semakin tercipta pula.

Masyarakat Indonesia, masih dalam proses dan pasca industri, sekaligus pasca reformasi-mengalami pelbagai macam tranformasi-, terutama menyangkut pelbagai aspek sosial psikologis dan budaya dalam kehidupan pribadi dan keluarga serta masyarakat. Pada dasarnya, transformasi sosial dan budaya dapat dikendalikan, khususnya dalam sektor pendidikan. Transformasi tersebut selalu dikaitkan dengan masyarakat industri. Adapun ciri-ciri masyarakat industri, menurut Torstern Husen (tanpa tahun, hlm.38 dan 94) sebagai berikut: [1] Tingginya mobilitas penduduk dari pedesaan ke perkotaan. [2] Perubahan struktur dan jumlah keluarga dari keluarga besar dan luas ke keluarga inti, ditandai dengan banyaknya perempuan bekerja di luar rumah, sehingga pendidikan anak menjadi terbengkalai, padahal kerjasama antara orang tua dan sekolah menjadi penting demi kesuksesan pendidikan anak. [3] Kondisi ekonomi nasional sangat ditentukan oleh hubungan dagang dengan pasar internasional yang semakin kompetitif. [4] Pendidikan formal hanya dijadikan wahana untuk meraih keinginan memperbaiki nasib, wahana untuk bergerak ke atas mencapai kehidupan sosial ekonomi 
yang lebih baik. Sistem seleksi tenaga kerja cenderung menentukan syarat tingkat pendidikan formal tertentu, yang karena persyaratan itu, tenaga kerja kurang terdidik semakin tersisih. Berkaitan dengan masalah ini, terdapat tiga orientasi yang berkembang dalam dunia pendidikan. Pertama, pendidikan berbasis nilai-nilai civil society hanya berorientasi ijazah, sehingga banyak lembaga yang bertindak sebagai produsen ijazah (pabrik ijazah) dengan aneka harga (Kompas, 09/12/1999). Kedua, madrasah hanya berorientasi pada sekolah tanpa peduli apakah madrasah itu akan mengembangkan potensi yang dimilkinya atau malah menghasilkan out put yang memahami zaman dan ujung-ujungnya menambah angka pengangguran (Azra, 1999: 164). Ketiga, pendidikan berbasis nilai-nilai civil society hanya berorientasi pada pendidikan itu sendiri, tanpa peduli apakah pendidikan itu formal, non formal ataupun informal, yang penting pendidikan dapat berlangsung, meminjam istilah Ivan Illich atau bahasanya Roem Topatimasang, "Sekolah itu Candu" (1999 cet. II).

Jadi, apabila pelbagai orientasi pendidikan berbasis nilai-nilai civil society di atas masih "berlaku" dalam kontek kekinian dan ke-disini-an, maka sulit kiranya-peluang-bagi masyarakat belajar (learning society) yang fokus kepada penanaman nilai-nilai civil society untuk tercipta. Kemudian, manusia moden saat ini, tidak sedikit yang menyukai "hal-hal yang berbau instan. Tidak mau menempuh pendidikan sebagaimana jalur yang "diundangkan", membeli gelar misalnya, yang hal ini didukung lembaga penjual gelar yang semakin menggila dan merajalela. Akan tetapi, apabila minimal tiga orientasi di atas tereliminir, maka peluang bagi masyarakat belajar (learning society) semakin besar-akan tercipta bahkan bisa jadi mudah terwujud.

\section{Masyarakat Belajar sebagai Saranan Penciptaan Pendidikan Berbasis Nilai-Nilai civil society}

Dalam proses penciptaan masyarakat belajar (learning society) yang memiliki kepedulian terhadap nilai-nilai civil society, perlu dilakukan, yaitu: [1] lingkungan atau jalur madrasah dan luar madrasah [2] dilaksanakan oleh pemerintah dan masyarakat [3] kegiatan yang tidak pernah putus atau disebut juga pendidikan seumur hidup (life long education).

Sedangkan upaya-usaha lain yang relatif bisa dilakukan dalam rangka mewujudkan masyarakat belajar (learning society) ada dua hal 
vital yang perlu menjadi perhatian, yakni: [1] pemberdayaan keluarga menjadi keluarga yang gemar membaca. Keluarga mengarahkan proses tumbuh beerkembangnya generasi muda dalam masyarakat madani. Keluarga menjadi tempat pertama dan utama dalam menumbuhkan berbasis nilai-nilai civil society untuk selalu mencoba, berpikir kritis, inovatif dan lain sebagainya. Kenapa keluarga? Karena keluarga mempunyai banyak fungsi, antara lain: fungsi keagamaan, cinta kasih, reproduksi, pendidikan, sosial dan lain-lain. [2] peningkatan partisipasi masyarakat. Bagaimana masyarakat dapat berfungsi sebagai kontrol sosial terhadap penerapan nilai-nilai civil society di tengah masyarakat.

Dalam masyarakat belajar (learning society), pendidikan berbasis nilai-nilai civil society diharapkan berasal dari, oleh, dan untuk masyarakat. Dengan demikian, pendidikan berbasis nilai-nilai civil society diharapkan dapat mempertebal rasa saling memiliki terhadap keadaan yang ada dalam masyarakat dan negara, yang pada gilirannya akan menumbuhkan rasa tanggung jawab yang tinggi terhadap keberlangsungan kehidupan masyarakat yang mengelilinginya. Akhirnya, dengan masyarakat belajar (learning society) diharapkan akan terwujud apa yang disebut masyarakat madani (civil society).

Perubahan adalah sebuah keniscayaan sejarah. Ia hadir mengiringi perjalanan hidup kita. Jatuh bangunnya peradaban manusia di masa lalu mengindikasikan bahwa proses perubahan selalu berjalan secara dinamis dan dialektis, tidak deterministik (bersifat menentukan). Perubahan, dengan demikian merupakan gambaran yang ideal dari sebuah cita-cita, dan refleksi kesadaran serta imaji dari masyarakat. Kehadirannya mampu membangkitkan energi terpendam dalam diri Muhammad Saw., Karl Mark, hingga Osama bin Laden. Energi yang misterius inilah yang kemudian menjadi tenaga pendorong perubahan yang sangat dasyat dibelahan dunia ini.

Luther King sempat memimpikan perubahan sosial, "keluar dari sebuah situasi yang membuat terasing (alienasi) dari dunianya, "pendidikan". Disana ada nuansa ketidakadilan, ketimpangan, penindasan, dan lain sebagainya. Mengubah situasi sosial memang bukan pekerjaan yang mudah, tetapi sejarah telah membuktikan bahwa manusia seperti Muhammad mampu berbuat sesuatubahkan merubah situasi Arab, menghapus perbudakan, misalnya 
dan seterusnya menuju kemerdekaan yang hakiki dan manfaatnya dirasakan sampai saat ini. Pendidikan berbasis nilai-nilai civil society diyakini memiliki unsur perubahan sosial. Pendidikan berbasis nilainilai civil society memiliki faktor-faktor penting yang mengiringi perubahan itu sendiri. Menurut Dr. Ausuf Ali (1998), seorang perintis sains-sains sosial Islam, mengatakan bahwa faktor- faktor perubahan pendidikan berbasis nilai-nilai civil society, meliputi: [1] munculnya kritik terhadap realitas dan praktik sosial yang ada, yang dilakukan oleh mereka cenderung terhadap tatanan baru [2] adanya paradigma baru tentang nilai-nilai, norma, dan sistem penjelas yang berbeda [3] partisipasi sosial yang dipilih oleh mereka yang cenderung dengan tatanan baru tersebut dalam mentransformasi masyarakat.

Masyarakat Madani tentunya bukan hanya sebuah gambaran ideal tentang cita praktik kehidupan bersama, tetapi lebih dari itu, ia merupakan sesuatu " yang ada disini", yang dekat dengan kehidupan kita. Tentunya bagaimana membangun masyarakat yang memilki tiga ciri: kebebasan, persamaan, dan toleransi. Merujuk pada Malik Fadjar (1999), masyarakat madani (civil society) yang ingin diwujudkan di Indonesia berorientasi pada: [1] masyarakat yang religius dan bermoral, [2] demokrasi pluralistik yang menghargai perbedaan pendapat, keanekaragaman suku, agama, dan budaya [3] tertib dan sadar hukum serta menjunjung tinggi hukum sebagai aturan tertinggi yang mengikat kehidupan bermasyarakat [4] mengakui mejunjung tinggi HAM, egalitarianisme, dan tidak diskriminatif [5] profesional dan skilful, memiliki keunggulan intelektual, keterampilan, dan profesionalisme yang komperatif dan kompetitif, dalam persaingan global [6] masyarakat yang terbuka dan memiliki tradisi belajar (learning).

Dengan demikian, dalam rangka mewujudkan masyarakat madani (civil society) diperlukan proses yang panjang dan kesabaran yang tak pernah henti. Dalam kontek kehidupan bangsa sekarang ini, dimana moralitas dan akhlak sudah hampir terkubur dalam gempita konsumerisme dan hedonisme, maka kehadiran pendidikan berbasis nilai-nilai civil society yang membebaskan menjadi suatu hal yang niscaya. Pendidikan yang berbasis nilai-nilai civil society membebaskan masyarakatnya dari; kebodohan, keterbelakangan, dan kemiskinan. Hal ini akan dapat tercipta tatkala pendidikan berbasis nilai-nilai civil society mampu memberikan pelayanan yang terbaik kepada siswa 
sebagai manusia dengan harkat dan martabatnya, unque individual; individu yang unik atau tak sama (John dan Hassan, 1995:616), yang bebas memberikan layanan agar mereka mampu melakukan aktualisasi diri, meminjam istilah Maslow, ilmuan psikologi.

Perwujudan masyarakat madani (civil society) di Indonesia, didorong melalui penciptaan masyarakat belajar (learning society). Inilah inti dan makna yang terkandung dalam masyarakat belajar. Sesungguhnya hakikat learning society merupakan "ruh" masyarakat madani. Masyarakat Belajarpun adalah proses menuju pendidikan yang membebaskan. Dalam masyarakat belajar, tidak ada obyektifikasi terhadap peserta didik, yang ada adalah subyektifikasi, peserta didik diposisikan sebagai warga dalam pendidikan. Apabila iklim ini tercipata, maka proses belajar mengajar menjadi lebih hidup dan lebih bermakna. Pada akhirnya, belajar adalah proses menyenangkan, menuju pada perubahan sikap yang lebih "baik".

Disinilah pendidikan berbasis nilai-nilai civil society memiliki peranan yang sangat penting. Sebab pada dasarnya pendidikan berbasis nilai-nilai civil society yang membuat peserta didik "bring educated". Hal ini berimplikasi kepada pendidikan berbasis nilainilai civil society yang dianggap bisa berperan mengkikis habis semua indikasi-indikasi "primitive culture". Dengan demikian akan terwujudlah apa yang disebut masyarakat madani (civil society).

Sedangkan kemungkinan adanya kekuatan "civil" sebagai bagian dari komunitas bangsa ini akan mengantarkan pada sebuah wacana yang saat ini sedang berkembang, yakni masyarakat madani. Wacana masyarakat madani di madrasah, merupakan wacana yang mengalami proses yang sangat panjang. Ia muncul bersamaan dengan proses modernisasi dan demokratisasi, terutama pada saat terjadi transformasi dari masyarakat feodal menuju masyarakat Barat modern, yang pada saat itu dikenal dengan istilah civil society.

Di tengah lemahnya peran negara (state) dalam menciptakan harapan masyarakat yang berbasis demokrasi, maka penguatan civil society merupakan agenda yang sangat penting (urgen). Secara teoritis, menurut Larry Diamond seperti dikutip Hasan Syadzly (Azra, 2003: iv) mengatakan bahwa civil society dapat memberikan kontribusi yang cukup besar bagi tumbuh kembangnya demokrasi. Pertama, pendidikan berbasis nilai-nilai civil society menyediakan 
wahana sumber daya politik, ekonomi, kebudayaan dan moral untuk menjaga dan mengawasi keseimbangan negara. Asosiasi independen dan media yang bebas memberikan dasar bagi pembatasan kekuasaan negara melalui kontrol publik. Kedua, beragam dan pluralnya dalam masyarakat sipil dengan pelbagai kepentingannya, bila diorganisir dan terkelola dengan baik, maka hal ini dapat menjadi dasar yang penting bagi persaingan yang demokrartis. Ketiga, pendidikan berbasis nilainilai civil society juga akan memperkaya peranan partai-partai politik dalam hal partisipasi politik, meningkatkan evektifitas politik dan meningkatkan kesadaran kewarganegaraan (citizenship). Keempat, pendidikan berbasis nilai-nilai civil society ikut menjaga stabilitas negara. Dalam arti bahwa pendidikan berbasis civil society, karena kemadiriannya terhadap negara, mampu menjaga independensinya yang berarti secara diam-diam mengarungi peran negara. Kelima, pendidikan berbasis nilai-nilai civil society sebagai wadah bagi seleksi dan lahirnya para pemimpin politik yang baru. Keenam, pendidikan berbasis nilai-nilai civil society menghalangi dominasi rezim otoriter.

Keprihatinan bangsa yang telah dilanda krisis multidimensi dan pelbagai aspek kehidupan-membuat peran pendidikan berbasis nilainilai civil society, khususnya di madrasah, dipertanyakan. Bahkan pendidikan berbasis nilai-nilai civil society secara tidak langsung diminta uintuk'bertanggungjawab'. Pendidikan pada dasarnya sangat berperan terhadap terwujudnya masyarakat madani (civil society), masyarakat yang gandrung akan adanya keadilan, egalitarianisme (persamaan) dan demokrasi.

Prinsip masyarakat belajar (learning society) adalah memberdayakan peran masyarakat dan keluarga dalam bidang pendidikan. Sedangkan civil society ditejemahkan sebagai masyarakat madani yang mengandung tiga hal, yakni agama, peradaban, dan perkotaan. Disini agama merupakan sumber, peradaban adalah prosesnya, dan masyarakat kota adalah hasilnya (Widodo,dkk (Ed) 2002:30).

Dalam rangka mewujudkan masyarakat madani (civil society), maka konsep masyarakat belajar (learning society) menjadi suatu hal yang niscaya dan bisa jadi merupakan 'satu-satunya' cara strategis dalam upaya mewujudkan masyarakat madani (civil society). Karena untuk mencipta masyarakat madani, dasarnya adalah pendidikan 
yang berbasis nilai-nilai civil society dan learning society (masyarakat belajar).

Maka, untuk memastikan pernyataan di atas dan melihat secara rigit serta menemukan 'ruh' masyarakat belajar (learning society) sebagai titik kejelasan-dalam upaya mencipta dan mewujudkan memiliki kesadaran yang tinggi akan pentingnya nilai-nilai civil society. Tanpa harus digerakkan oleh institusi dalam bentuk apapun dan meniscayakan peran keluarga dan lingkungan. Masyarakat Belajar, menitikberatkan pada bagaimana pendidikan berbasis nilainilai civil society dapat diperoleh dari mana saja dan kapan saja, tidak terikat dengan ruang dan waktu.

Setiap aktivitas yang dilakukan dalam pendidikan berbasis nilainilai civil society selalu dipahami sebagai proses belajar. Karenanya, madrasah itu ada di mana-mana, tidak hanya ada dalam madrasah yang sering disebut dengan formal institusional. Dalam masyarakat belajar, pendidikan berbasis nilai-nilai civil society dilaksanakan dalam keluarga dan lingkungan masyarakat termasuk penentu sukses tidaknya men-konstruk anak didik menuju pembentukan yang berpotensi memiliki tiga bidang kompetensi; pertama, bidang kognitif kedua, afektif, dan ketiga, psikomotorik. Sehingga pendidikan menjadi tanggung jawab bersama.

Prinsip-prinsip yang sering diambil dari masyarakat belajar (learning society) dalam menanamkan pendidikan nilai-nilai civil society antara lain: Pengetahuan dibangun oleh anak didik secara aktif, tekanan dalam proses belajar terletak pada siswa, mengajar adalah membantu siswa belajar, tekanan dalam proses belajar lebih pada proses bukan pada hasil akhir dan guru atau pendidik bertindak sebagai fasilitator.

Pada intinya, masyarakat madani (civil society) adalah masyarakat yang berperadaban, masyarakat yang hidupnya didasarkan pada ruh Islam, masyarakat yang menjunjung tinggi nilai-nilai demokrasi, masyarakat yang cinta keadilan, masyarakat yang menghargai persamaan hak, dan prinsip agalitarianime. Untuk mewujudkan masyarakat madani, madrasah harus mampu menciptakan masyarakat belajar di dalam dan di luar kelas. Dengan lahir dan terciptanya masyarakat belajar di madrasah, sesungguhnya dengan sendirinya masyarakat madani akan tercipta tidak hanya di madrasah namun juga masyarakat luas. 
Baharuddin - Menggagas Pendidikan Berbasis Nilai-Nilai...

\section{E. Simpulan}

Terbentuknya masyarakat belajar (learning society) di madrasah sebagai upaya mewujudkan masyarakat madani (civil society), dilakukan mensinergikan kesamaan visi antara pihak terkait; pembuat kebijakan publik (public policy), pemerintah, pelaksana kebijakan publik, "institusi atau lembaga pendidikan", para pendidik, orang tua, anak didik, pemerhati pendidikan dan atau para pakar pendidikan, lembaga atau organisasi kemasyarakatan, lembaga swadaya masyarakat dan masyarakat pada umumnya.

Dalam mengembangkan masyarakat belajar (learning society), seyogyanya dipahami sebagai usaha dan kebutuhan bersama. Oleh karenanya, kerjasama antar pihak terkait, merupakan hal yang niscaya. Dalam usaha mencipta iklim masyarakat belajar (learning society) terutama di madrasah, sebaiknya seorang pendidik tidak lagi bertindak sebagai subjek, akan tetapi, pendidik bertindak sebagai motivator dengan tidak menafikan pendidik sebagai teman berpikir anak didik yang senantiasa memiliki pengetahuan yang lebih, anak didik diposisikan sebagai subjek.

Pendidikhendaknyamengubah paradigma"mengajar" (teaaching) menjadi belajar (learning), sehingga tercipta masyarakat belajar (learning society). Masyarakat hendaknya meninggalkan paradigma bahwa pendidikan itu hanya ada di madrasah, apalagi memasrahkan atau bahkan mengasumsikan madrasalah yang bertanggung jawab atas masa depan putra-putrinya, termasuk moralnya.

Pada gilirannya, civic culture (budaya keadaban) dapat mendorong terciptanya iklim kondusif masyarakat madani (civil society). Disampng itu, pemerintah dan masyarakat, hendaknya memahami ruh masyarakat madani sebagai langkah dalam mewujudkan: nilainilai persamaan antar warga, keadilan, pluralisme, dan penghormatan terhadap hak-hak asasi manusia (HAM) serta terbangunnya keadaban (civility).

Hendaknya, pendidikan politik warga negara (civic education) bukan hanya ditekankan pada aspek peningkatan kesadaran dan pengetahuan, tetapi juga dengan melakukan fasilitasi peserta didik maupun warga negara dengan tujuan mendorong agar lebih menguatkan partisipasi masyarakat dengan secara langsung melibatkan mereka dalam melakukan kontrol kebijakan publik (public polcy). 


\section{DAFTAR PUSTAKA}

Ali Hasan, M., dan Mukti Ali, 2003, Kapita Selekta Pendidikan Islam, Jakarta: CV. Pedoman Ilmu Jaya.

Azra, Azyumardi,1999a, Esai-esai Intelektual Muslim dan Pendidikan Islam, Jakarta: Logos.

1999b, Pendidikan Islam, Tradisi dan Modernisasi Menuju Milenium Baru, Jakarta: Logos.

Azizy, Qodry, 2004, Melawan Globalisasi, Reinterpretasi ajaran Islam: Persiapan SDM dan Terciptanya Masyarakat Madani, Yogyakarta: Pustaka Pelajar.

Burhanuddin, (ed), 2003, Mencari Akar Kultural Civil Society di Indonesia, Jakarta: INCIS CSSP-USAID.

Daradjat, Zakiah, dkk. 1996, Ilmu Pendidikan Islam, Jakarta: Bumi Aksara dan Depag RI.

DePorter, Bobbi dan Hernack, Mike, 2002, Quantum Learning: Membiasakan Belajar Nyaman dan Menyenangkan, Bandung: Kaifa.

Djati Sidi, Indra, 2001, Menuju Masyarakat Belajar, Jakarta: Paramadina.

Echols, John M, danShadily, Hassan, 1995, Kamus Inggris Indonesia, Jakarta: Gramedia Pustaka Utama.

Fadjar, A. Malik, et al.,1999, Platform Reformasi Pendidikan dan Pengembangan Sumber Daya Manusia, Jakarta: Ditjen Binbaga Islam, Depag RI.

Furqan, Arief. 1992, Pengantar Metode Penelitian Kualitatif, Surabaya: Usaha Nasional.

Freire, Paulo, 2004, Pendidikan Alat Perlawanan: Teori Pendidikan Radikal Paulo Freire, Yogyakarta: Resist Book.

Hadi, Sutrisno, 1987a, Metode Researh I, Yogyakarta: Afsed. ,1987b, Metode Researh I, Yogyakarta: Afsed.

Hikam, Muhammad A.S., 1996, Demokrasi dan Civil Society, Jakarta: LP3ES

1999, Pengantar (1) Nahdlatul Ulama, Civil Society, dan Proyek Pencerahan, dalam Ahmad Baso, Civil Society versus Masyarakat Madani: Arkeologi Pemikiran Civil Society Dalam Wacana 
Baharuddin - Menggagas Pendidikan Berbasis Nilai-Nilai...

Islam Indonesia. Bandung: Pustaka Hidayah dan Lakpesdam NU.

Husen, Torsten, 1995, Masyarakat Belajar, terj.Surono Hergsewono, Jakarta: Raja Grafindo Persada. ,2000, Islam, Demokratisasi dan Pemberdayaan Civil Society, Jakarta: Erlangga.

Khudari shaleh, A., (Ed.) 2003, Pemikiran Islam Kontemporer, Yogyakarta, Jendela.

Nadjib Zuhdi dan Williem Kehelay, 2000, Kamus Lengkap Praktis, Surabaya, Fajar Mulya.

Nurhadi dan Agus Gerrad Senduk, 2003, Pembelajaran Kontekstual, Malang: UM PRESS.

Pius A. Partanto dan M. Dahlan al-Barry, 1994, Kamus Ilmiah Populer, Arkola: Surabaya.

Rahardjo, Dawan, 1999, Masyarakat Madani:Agama, Kelas Menengah dan Perubahan Sosial, Jakarta: LP3ES Indonesia.

Ronisef, Syafnir, dkk., (Ed.) 2003, Menggugat Benang Kusut Pendidikan, Jakarta: Transformasi UNJ dan Pustaka Pelajar.

Rozak, Abdul, dkk.., (Ed.) 2003, Civic Education: Demokrasi, Hak Asasi Manusia, Masyarakat Madani, ICCE UIN Syarif Hidayatullah, Jakarta.

Subhan, Imam, (Ed.) 2003, Siasat Gerakan Kota: Menuju Masyarakat Baru, Yogyakarta, Penerbit Shalahuddin.

Sidi, Indra Djati, 2001, Menuju Masyarakat Belajar, Jakarta: Paramadina dan PT.Logos Wacana Ilmu.

Soejono dan Abdurrahman, 1999, Metode Penelitian: Suatu Pemikiran dan Penerapan, Jakarta, Rineka Cipta.

Sufyanto, 2001, Masyarakat Tamaddun: Kritik Hermeneutik Masyarakat Madani Noercholis Madjid, Pustaka Pelajar dan YLP2IF, Yogyakarta.

Suharsono, "Ideologi Intelektual", dalam Warta Himpunan, Edisi Juni-Agustus 1998.

Surachmad, Winarno, 1990, Pengantar Penelitian Ilmiah: Dasar, Metode, dan Teknik. Bandung.

Suyadi, 2005, Pendidikan dalam Perspektif al-Qur'an, Yogyakarta: Mikraj. 
Topatimasang, Roem, 1999 cet. II, Sekolah itu Candu, Yogyakarta: Pustaka Pelajar.

Usman, Widodo, dkk.., (Ed) 2000, Membongkar Mitos Masyarakat Madani, Pustaka Pelajar, Yogyakarta.

Suparlan. 2011. Tanya Jawab Pengembangan Kurikulum dan Materi Pembelajaran. Jakarta: Bumi Aksara.

Nana Syaodih Sukmadinata. 2002. Pengembangan Kurikulum Teori dan Praktek, Bandung : Remaja Rosda Karya, Cet. V. 
Baharuddin - Menggagas Pendidikan Berbasis Nilai-Nilai... 